in May of that year, when Mr. A. Timmins, Stud. Inst. C.E., kindly showed me the series of specimens, at Runcorn. Mr. A. Timmins had himself recognized the fact that the beds in question were limestones, and had, in fact, made a rough analysis of them, which I urged him to send to the Manchester Geological Society, with a note from myself as to their geological identification, which $I$ at once recognized-having shortly before, through the courtesy of $\mathrm{Mr}$. Vivian, of the North England Rock Boring Company, examined the fine series of cores obtained at Clayton Vale, east of Manchester, where the Ardwick Series was penetrated. In the fifth report of the Underground Water Committee of the British Association, read at Sheffield in August, 1879, and printed in the volume for that year, I alluded to my identification, and in June, 1880, I published the detailed section of the Winwick boring, drawn up from my notes of the samples, in my paper published in the Manchester Geological Society's Transactions, on "Further Notes on Triassic Borings near Warrington." From which, perhaps, I may be permitted to quote the following passages. "These Coal-measure deposits occurring at a depth of only 340 feet or 113 yards from the surface, cannot be regarded as a discovery of the highest commercial interest, for looking to the westerly attenuation of thickness of the Coal-measures of South Lancashire, to which I have already drawn the attention of the Society, there can be little doubt but that the Manchester Coal-field will occur at a less depth beneath the limestone than at Manchester, in which case a valuable and workable Coal-field may be under the London and North Western Railway at Parkside, where a boring has recently been carried out," .... and, "should the limestones of Winwick belong to the same horizon as those of the Manchester Coal-field, it is in the highest degree probable that another 600 feet, and possibly much less, would reach the Openshaw Coal, or its equivalents."

H. M. Geol. Survey, 54, West Parade, Rhyl.

Chas. De Rance, F.G.S., Assoc. Inst. C.E.

\title{
MR. H. H. HOWORTH ON THE SUDDEN EXTINCTION OF THE MAMMOTH.
}

Sik, -As one of a numerous body of students of that most fascinating science Geology, I venture to address you a few lines to ask you to use your influence to induce writers, at least in your own Magazine, to make use of their own language in their scientific papers, and so to largely to increase the number of their readers. In your September Number is a paper on a subject in which Iand many other equally unlearned students of nature-take much interest. From the cause above named, all who are not thoronghly versed in both Latin and German are bound to take on trust evidence that is quoted in support of the theory brought forward, which evidence, had it been given in English, would have considerably increased the interest in the paper of myself and many other of your readers. Why should Englishmen, more than any other men, err in this way? We have a language much more expressive 
than either Latin, French, or German, yet some of our learned countrymen seem to delight in writing their scientific papers in one of those foreign languages. In most foreign works, I think you will find quotations translated into the language of the country; why not in ours?

IgNORAMUS.

Bristol, Oct., 1881.

\section{MISCFIIANEOUS.}

The Buackhanth Subsidunces.--The Report of the Committee for the exploration of these subsidences has just been published by the Lewisham and Blackheath Scientific Association. Unfortunately they have been unable to arrive at any positive solution of the problem which lay before them; but Mr. T. V. Holmes, F.G.S., has appended some observations, accompanied by a plan and sections, which acquaint us with all the facts of the case, and render most plausible his view that the plateau of Blackheath was chosen for the site of Dane's Holes, of which the holes recently exposed are examples. (See Geol. MAg. for July, 1881, p. 336.)

Postscript to Note on a New English Homalonotus from the Devonian, Torquay, S. Devon (see p. 489). - Since the foregoing was written I have been favoured by $\mathrm{Mr}$. Champernowne with a series of specimens obtained by him from the same locality as yielded the Momalonotus Champernownei, described above. These have been carefully examined by my colleague, Mr. R. Etheridge, F.R.S., who has determined them thus:-

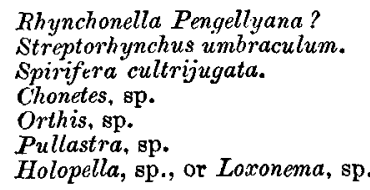

(and one or two other indeterminate Gasteropoda.) Cyrtoceras, sp. Orthoceras, sp. Pleurodictyum problematicum. Petraia, sp.

There are also several parts of Homalonotus, probably representing two other species, and a caudal portion which may have belonged to H. Champernownei, H. Woodw.-H.W.

Mr. R. Etheridge, F.R.S., President Geol. Soc. London, who has so ably filled the post of Palæontologist to H.M. Geological Survey in the Museum of Practical Geology, Jermyn Street, for the past twenty-four years, has just accepted the office of Assistant-Keeper to the Department of Geology in the British Museum (Natural History), S.W., where he will in future be associated with Dr. H. Woodward, F.R.S. Mr. Etheridge's eminent services in Geology and Palæontology, and his long connection with this MAGAzINe, as one of its Editors, have rendered his name widely known to the scientific world. All who know Mr. Etheridge will rejoice at any advancement which will afford him more leisure for the pursuit of his palæontological studies, and will join us in expressing the hope that he may long be spared to enjoy his present position. Mr. Etheridge's address will in future be: "British Museum (Natural History), Cromwell Road, South Kensington, S.W." 